\title{
SASTRA KLASIK SEBAGAI WAHANA EFEKTIF DALAM PENGEMBANGAN PENDIDIKAN KARAKTER
}

\author{
E. Kosasih \\ Jurusan Pendidikan Bahasa dan Sastra Indonesia, FPBS UPI \\ Korespondensi: Jln. Dr. Setiabudhi 229 Bandung 40154 \\ Pos-el: ekos_kosasih@yahoo.com
}

\begin{abstract}
Abstrak
Sastra Klasik sebagai Wahana Efektif Pengembangan Pendidikan Karakter. Pelajaran sastra klasik merupakan wahana efektif bagi pengembangan karakter siswa. Dalam sastra klasik ada unsur budaya, sejarah, bahkan unsur ideologi di samping aspek emosional, intelektual, sosial, dan moralitas. Unsur-unsur itu pula yang selama ini merupakan bidang kajian dalam pengembangan kepribadian. Oleh karena itu, pengembangan pendidikan kepribadian (baca: karakter) melalui pengajaran sastra klasik bukanlah upaya yang mengada-ada. Sastra klasik dapat membantu pembentukan karakter siswa, melalui jalinan cerita yang menyentuh, pilihan kata yang menggugah, ataupun kekuatan konflik yang menggetarkan temanya yang mencengangkan dan heroik. Justru dengan sastra klasik itulah siswa dapat memperoleh kesadaran, tanpa merasa dipaksa dan digurui. Untuk itu, pembelajarannya tidak cukup apabila berkutat pada soal teori. Ada aspek lain yang yang lebih penting, yaitu apresiasi dan kreasi. Kedua aspek tersebut bisa memberikan pengalaman dan kepribadian bersastra, terutama di dalam pembentukan karakter-karakter tertentu pada diri siswa.
\end{abstract}

Kata kunci: Sastra klasik, pendidikan karakter, potensi siswa, strategi pembelajaran

\begin{abstract}
Classic literature as an effective way in improving education of character.A lesson of classic literature is an effective mode for improving student's character. Some elements of classic literature include culture element, history, beside emotional aspect, intellectual, social, and morality. That element as long as now is an inspection surface in a personality improvement. Therefore, improvement of personality education (read: character) by means of classic literature is not fabricating efforts. A classic literature is able to help building student's character, by means of touching story's combination, shaking of words selection, or a power of conflict which was tremble his friend shock and heroism. Exactly, by a classic literature, a student is able get a conscious, without feeling to be forced and taught. So, learning of it is not enough if only concentrate to a theory. Another aspect is more important, that is an appreciation and creation. Both of that aspect is able to give an experience and literature personality, especially in certain characters building of student's personal.
\end{abstract}

Keywords: Classic literature, character education, students potential, learning's strategy

\section{PENDAHULUAN}

Arah kebijakan pengajaran sastra secara tegas dinyatakan dalam Permendiknas Nomor 22 Tahun 2006 tentang Standar Isi untuk Satuan
Pendidikan Dasar dan Menengah. Antara lain dijelaskan bahwa tujuan pengajaran sastra agar peserta didik memiliki kemampuan (1) menikmati dan memanfaatkan karya sastra untuk 
memperluas wawasan, memperhalus budi pekerti, serta meningkatkan pengetahuan dan kemampuan berbahasa, dan; (2) menghargai dan mengembangkan sastra Indonesia sebagai khazanah budaya dan intelektual manusia Indonesia.

Berdasarkan tujuan tersebut, sudah jelas bahwa penekanan pengajaran sastra berorientasi pada pengembangan karakter siswa, di samping pada manfaat secara estetis. Penekanan tersebut sudah seharusnya pula menjadi bagian terpenting di dalam pembelajarannya yang meliputi empat ranah keterampilan bersastra: menyimak, berbicara, membaca, dan menulis. Kegiatan bersastra di sekolah perlu mengembangkan kecakapan yang bersifat indrawi, penalaran, afektif, sosial, bahkan sifat-sifat religius siswa. Terlepas dari tujuan pembelajarannya, karya sastra itu sendiri sesungguhnya sudah memberikan peluang-peluang untuk mengembangkan kecakapan-kecakapan sebagaimana yang disebutkan di atas. Oleh karena itu, apabila dilakukan dengan benar, pengajaran sastra akan dapat menyediakan kesempatan untuk mengembangkan kecakapan-kecakapan tersebut, bahkan dapat melebihi dari yang mungkin dikembangkan oleh mata pelajaran yang lain. Pembelajaran sastra memberikan peluang yang potensial di dalam pengembangan pendidikan karakter di samping pengalamanpengalaman estetis itu sendiri, yang disebut Wellek \& Warren (1989: 35) sebagai bentuk ketenangan pikiran.

Karakter merupakan nilai-nilai perilaku manusia yang berhubungan dengan Tuhan, diri sendiri, sesama manusia, lingkungan, dan kebangsaan yang terwujud dalam pikiran, sikap, perasaan, perkataan, dan perbuatan berdasarkan norma-norma agama, hukum, tata krama, budaya, dan adat istiadat. Adapun yang dimaksud dengan pendidikan karakter adalah suatu sistem penanaman nilai-nilai karakter kepada warga sekolah yang meliputi komponen pengetahuan, kesadaran atau kemauan, dan tindakan untuk melaksanakan nilainilai tersebut, baik terhadap Allah SWT, diri sendiri, sesama, lingkungan, maupun kebangsaan sehingga menjadi manusia yang paripurna. Di sekolah pendidikan karakter diintegrasikan dalam suatu pembelajaran tertentu dan dikaitkan dengan konteks kehidupan nyata.Dengan demikian, pembelajaran nilai-nilai karakter tidak hanya pada tataran kognitif, tetapi menyentuh pada internalisasi, dan pengamalan nyata dalam kehidupan peserta didik sehari-hari di masyarakat. Permasalahannya, pendidikan karakter di sekolah selama ini baru menyentuh pada tingkatan pengenalan norma atau nilai-nilai, dan belum pada tingkatan internalisasi dan tindakan nyata dalam kehidupan seharihari.Dengandemikian, kehadiran model sangatlahpenting di dalam fase pertumbuhan dan pembentukan siswa melalui proses imitasi dan identifikasi (Al-Banjari, 2008: 310-311).

Dalam kepentingan itulah, penulis bermaksud memaparkan urgensitas pembumian sastra klasik di sekolah. Di dalam KTSP Bahasa Indonesia SMP/SMA, kompetensi tersebut dinyatakan secara tersurat. Persoalannya kemudian adalah strategi pembelajaranya yang dapat dilakukan guru dan siswa di kelas. Persoalan itu pula yang akan dikemukakan di dalam tulisan ini yakni tentang nilai-nilai pembentukan karakter yang potensial di dalam sastra klasik itu sendiri. Di samping itu, akan dipaparkan pula unsur-unsur pembelajarannya, yang meliputi unsur siswa, materi, metode, materi dan evaluasinya.

\section{SASTRA KLASIK, SARAT PENDIDIKAN MORAL}

Secara umum, sastra klasik itu padat dengan nilai-nilai moral, dipenuhi nilai-nilai didaktis yang menggugah dan memotivasi. Sastra klasikmerupakan 
sarana pembuka pintu-pintu penemuan jati diri asali bangsa, memberikan petualangan-petualangan atas kebenarankebenaran masa silam (Kosasih, 2008: 917). Dengan menyimak atau membaca karya sastra klasik, para siswa seolaholah berpetualang bersama pengalaman imajinatif yang herois bersama dengan sentuhan-sentuhan nilai-nilai spiritualitas yang sangat kental. Barangkali pengalaman batin semacam itu tidak lagi mereka dapatkan dalam kehidupan mereka, tidak terbayangkan pula di dalam kenyataan sehari-hari. Apabila disuguhkan dengan baik, sastra klasik bisa menjadi suatu pengalaman pembelajaran yang sungguh mengasyikkan. Sastra klasik sungguh memberikan manfaat bersifat mendidik, namun tidak menggurui. Kegiatan mengapresiasi sastra klasik berarti mengenalkan para siswa pada berbagai karakter yang sebagian besar merpakan refleksi dari realitas kehidupan bangsanya secara asali.

Agar tujuan pembelajaran sastra (klasik) tercapai, diperlukan pendekatan yang tepat sehingga sastra itu memiliki posisi yang kuat di tengah-tengah masyarakatnya (Esten, 1999: 34). Terdapat beberapa pendekatan pengajaran sastra, antara lain, pendekatan moral, estetika dan stilistika, resepsi, dan tidak terkecuali pula dengan hermeneutik sebagai ilmu tafsir teks (Sumaryono, 1993: 28). Pada dasarnya semua pendekatan tersebut baik, hanya saja perlu diperhatikan pendekatan yang paling dikuasai guru sastra dan pendekatan yang paling sesuai dengan keadaan siswa. Di samping itu, kehadiran sarana belajar, terutama buku-buku sastra sangatlah utama. Buku-buku sastra memainkan peranan penting dalam kehidupan anak-anak, tetapi peranan buku-buku tersebut tergantung pula pada orang tua dan para guru yang membimbing mereka. Para orang tua dan guru bertanggung jawab bagi penyediaan buku-buku sastra serta menyebarluaskan warisan sastra yang telah terserat dan tersirat dalam rima anak-anak, dongengdongeng tradisional, dan novel-novel yang bermutu.

Demikianlah

pengajaran sastra (klasik) untuk membentuk moral siswa yang berbudi mulia (Mustika, 2011: 57). Hanya saja, pengajaran sastra klasik akan berhadapan dengan kendala bahasa yang tidak lagi menjaman. Hal tersebut bisa menjadi faktor utama kurang diminatinya sastra klasik oleh para siswa. Sastra klasik pada umumnya masih menggunakan bahasa Melayu lama. Supaya lebih diakrabi para siswa, bahasa pengantar karya-karya perlu diadaptasi terlebih dahulu ke dalam bahasa yang sesuai dengan tingkat pemahaman para siswa.

Bagaimanapun, suatu karya memerlukan penggunaan bahasa yang efektif sehingga membuahkan pengalaman-pengalaman yang estetik. Bahasa itu sendiri, menurut Ricoeur (2002: 76-77) merupakan bahan yang bisa disubmisikan sesuai aturan-aturan yang bentuknya berwujud karya seni dan karya-karya wcana lainnya. Penggunaan bahasa yang imajinatif dapat menghasilkan respons - respons intelektual, emosional, dan spiritual. Hal ini akan memudahkan siswa di dalam merasakan dan menghayati sang tokoh, aneka konflik, berbagai unsur dalam suatu latar, dan masalah-masalah kesemestaan umat manusia, juga akan dapat membantu mereka dalam mengalami keceriaan/kesenangan dari keindahan, keajaiban, kelucuan atau keputusasaan dari kesedihdukaan, ketidakadilan, dan kekurangajaran.

Secara umum, pergaulan siswa dengan sastra-sastra itu akan memperoleh berbagai manfaat. Selain membantu dalam peningkatan keterampilan berbahasa, meningkatkan pengetahuan budaya, serta mengembangkan cipta dan rasa, menurut Rahmanto (1988: 16-24) 
pengajaran sastra dapat menunjang pembentukan watak.

a. Sastra memberi kesenangan, kegembiraan, dan kenikmatan (Wellek \& Warren, 1989: 24-36). Kebermanfaatan dari karya sastra klasik dapat pula tercapai apabila sastra itu disajikan dengan kemasan dan ilustrasi menarik, bahasa yang relevan, juga memberikan pengalaman-pengalaman dan wawasan-wawasan baru. Karakter dari tokoh-tokoh dalam karya sastra klasik dapat mendorong dan mengajari siswa dalam mengendalikan berbagai emosi, misalnya benci, cemas, khawatir, takut, bangga, angkuh, sombong, dan sebagainya. Dengan cara demikian, para siswa akan selalu betah dan asyik, selalu ingin membaca bukubuku sastra klasik apapun wujudnya: pantun, dongeng, hikayat, dan yang lainnya. Kian banyak mereka membaca, semakin banyak kegembiraan dan kenikmatan yang mereka peroleh. Untuk itu, guru perlu melakukan langkah-langkah berikut.

1) Mendorong siswa untuk mengenali lebih banyak -jenis karya sastra kasik. Tidak hanya dongeng, pantun, ataupun tekateki, tetapi juga cerita-cerita hikayat dan cerita-cerita sufistik

2) Membantu siswa dalam menemukan daya tarik, kebermanfaatan, ataupun kebermaknaan dari karya-karya itu bagi diri siswa. Dari sebuah cerita legenda, misalnya, siswa tidak hanya mendapatkan hiburan, tetapi nilai-nilai didaktis yang bisa membentuk karakternya, baik dari segi keagamaan, keluarga, ataupun kemasyarakatan.

3) Memunculkan berbagai problema yang mendorong daya apresiasi dan daya kritis siswa atas kayakarya klasik itu dengan berbagai kegiatan pembelajaran, tidak hanya membaca ataupun menyimak, tetapi juga berdiskusi, studi literatur, bermain peran.

4) Memotivasi siswa untuk melakukan kreasi-kreasi sastra dari karya-karya klasik itu, misanya berupa penyaduran ataupun pementasan.

b. Sastra dapat mengembangkan imajinasi siswa dan membantu mereka mempertimbangkan dan memikirkan alam, insan, pengalaman, atau gagasan dengan berbagai cara (Rahmanto, 1988: 19-22). Berkaitan dengan karya sastra klasik, karya itu pun harus membangkitkan keingintahuan, kepenasaranan siswa tentang suatu hal, baik itu berkenaan dengan tokoh, latar, dan unsur-unsur lainnya. Hal itu, terutama, pada karya-karya klasik semacam legenda atau pun fabel. Misalnya, mendorong siswa untuk memikirkan dan mengimajinasikan hubungan latar pada legenda Sangkuriang dengan Gunung Tangkuban Parahu atau dongeng si Malinkundang dengan sosok batu di suatu tempat yang mirip orang.

Siswa dapat pula mengimajinasikan dirinya, seandainya menjadi Pak Belalang atau Lebai Malang, yang memasuki abad modern seperti sekarang. Siswa mendiskusikan juga keberadaan sosok orang yang berwatak seperti Pak Pandir atau Mat Janin, yakni dua tokoh yang berawatak bodoh, di lingkungan sekitarnya.

c. Sastra dapat memberikan pengalaman-pengalaman aneh yang seolah-olah dialami sendiri oleh siswa. Perspektif-perspektif atau pandangan-pandangan baru akan diturunkan sebagaimana halnya seorang siswa di dalam memperoleh serta memiliki pengalaman aneh seperti itu melalui sastra. Apalagi 
karya-karya sastra klasik pada umumnya membawa penikmatnya ke dalam pengalaman yang penuh dengan kegaiban, sebagai cakrawala baru yang penuh daya imajinatif bagi para siswa. Sastra klask menyediakan pengalaman aneh yang bertolak belakang dengan kehidupan nyata siswa pada zaman kekinian.

d. Sastra dapat mengembangkan wawasan siswa menjadi perilaku insani yang berkarakter. Sebagaimana yang dapat dimaklumi sastra merefleksikan suatu kehidupan ideal yang imajinatif ke dalam kehidupan yang seolah-olah nyata di hadapan siswa. Sastra sangat ampuh dalam membentuk pembayangan atas sosok yang perlu diteladani (herois) dalam kehidupan siswa. Sastra dapat memperlihatkan kepada siswa betapa insan-insan lainnya hidup dan terjadi kapan saja dan di mana saja. Kesadaran luas mengenai kehidupan tokoh tertentu dengan berbagai karakter idealnya dapat membentuk pemahaman dan internalisasi kesadaran bagi siswa, disadari ataupun tidak. Melalui upaya kegiatan pengenalan terhadap berbagai karya sastra klasik, siswa memperoleh berbagai persepsi pribadi sendiri mengenai kehidup tokoh yang perlu diteladaninya. Dengan demikian, pemahaman dan konsesi tentang sosok tokoh yang barkarekter ideal bisa menjelma menjadi perilaku sisiwa itu sendiri di dalam kehidupannya secara nyata.

e. Sastra dapat menyajikan dan dapat memperkenalkan kesemestaan pengalaman kepada siswa. Tidak terkecuali sastra klasik, di dalamnya sarat dengan banyak nilai: keberanian, ketaqwaan, kesatrian, kesetiaan, persahabatan, kesabaran, kejujuran, dan yang lainnya. Nilainilai tersebut tetap menjaman dan relevan bagi para siswa dalam masa kekinian. Sastra klasik juga membantu siswa ke arah pemahaman nilai kebangsaan yang lebih asali, baik itu di dalam hubungan dengan sang Khalik, kemasyarakatan, ataupun dengan penguasa.Dengan caranya sendiri, sastra klasik mengiluminasikan segala kehidupan umat manusia, sastra memancarkan serta menyiarkan cahayanya mengenai segalanya yang baik dan bermakna dalam kehidupan umat manusia, dan juga menyoroti hal-hal yang hitam dan gelap serta kemerosotan nilai dalam pengalaman insani.

f. Sastra merupakan sumber utama bagi penerusan dan penyebaran warisan sastra dari satu generasi ke generasi berikutnya. Terutama sastra klasik memainkan peranan penting dalam pemahaman dan penilaian warisan budaya manusia. Pengembangan sikap-sikap positif siswa kearah budaya bangsanya sendiri sendiri sangat penting bagi perkembangan sosial dan watak siswa. Sastra klasik mengilustrasikan berbagai nilai dan budaya masyarakatnya pada zaman lampau dan siswa dapat mengkritisi, memilih, dan meneruskannya kembali pada zamannya pada masa kini dan masa datang.

Demikianlah beberapa manfaat pengajaran sastra klasik bagi perkembangan karakter siswa. Secara umum, dengan pengajaran tersebut siswa akan tumbuh menjadi pribadi yang memiliki harga diri dan jati diri kebangsaan yang asali dan mulia. Dengan berbekal wawasan dan apresiasi yang mendalam mengenai nilai-nilai bangsanya yang asli, secara perlahan dapat terbentuk pribadi siswa yang kuat dengan motivasi yang tinggi, dan kontrol diri yang baik. Siswa pun dapat menjalani dan mengatasi masalah-masalah kehidupan secara tepat dan bijak. 


\section{STRATEGI PEMBELAJARAN SASTRA KLASIK}

Pembelajaran sastra, lebih-lebih yang bermisi pada pengembangan karakter siswa, tidak cukup apabila berkutat pada soal teori sastra. Ada aspek lain yang yang lebih penting, yaitu apresiasi dan kreasi sastra. Kedua aspek tersebut memberikan pengalaman dan kemampuan bersastra secara lebih optimal, di samping pula mengarah pada pembentukan karakter-karakter tertentu pada diri siswa.

Apresiasi sastra lebih menekankan pada penikmatan karya sastra dengan cara membaca atau menyimaknya. Berbagai jenis karya klasik yang dapat disajikan kepada para siswa untuk lebih dikenal dan dinikmatinya, misalnya dongeng dan hikayat. Sedangkan kreasi sastra lebih bersentuhan dengan kemampuan siswa di dalam mencipta. Pengalaman batin, gejolak jiwa, dan imajnasi merupakan sejumlah daya yang mungkin muncul setelah mengapresiasi karya sastra. Daya-daya tersebut diharapkan diekspresikan siswa ke dalam berbagai bentuk kegiatan bersastra, baik itu sara lisan, tertulis, ataupun performansi. Berikutkomponenkomponen penting di dalam pengembangan strategi pembelajaran sastra klasik.

\section{Penggalian Potensi Siswa}

Siswa adalah individu-individu yang unik. Mereka mempunyai sisi-sisi kecerdasan yang cenderung berbeda satu sama lain. Howard Gardner (Chatib, 2010: 56) menyebut delapan kecerdasan: kecerdasan linguistik, matematis-logis, visual-spasial, musikal, kinestetik, interpersonal, intrapersonal, dan naturalis. Sementara itu, dalam teori domain (Djahiri, 1996) ada tiga potensi belajar yang dimiliki oleh seorang siswa, yakni kognitif, afektif, dan psikomotor. Potensipotensi itulah yang harus digali dari diri siswa di dalam proses pembelajarannya. Berkaitan dengan pengembangan karakter siswa, hal itu lebih banyak berkaitan dengan potensi afektif. Menurut Kosasih Djahiri (1996: 10), ada delapan indikator afektual, yakni emosi, feeling, cita-cita kemauan, kecintaan, sikap, sistem nilai, dan keyakinan. Nilai-nilai etis, spiritual, dan moral itu, menurut Jensen (2008: 117) akan berengaruh pada apa, kapan, bagaimana, dan mengapa seorang siswa tidak bisa dan bisa belajar sesuatu.

Pengembangan potensi afeksisangat berpengaruh terhadap internalisasi karakteristik tertentu pada diri siswa dan itu terkait pula dengan sistem pembelajaran emosional dan sosial (Given, 2007: 59-61). Sastra klasik sebagai sastra yang sarat nilai merupakan model materi pembelajaran yang dapat memperkaya batin siswa dengan berbagai indikator afektual di dalamnya. Melalui kegiatan bersastra siswa juga dapat terasah secara emosional dan sosial. Siswa dapat lebih peduli terhadap sikapsikap kemanusiaan: kejujuran, keberanian, demokratisasi, dan sejenisnya. Untuk itu, pemaduan kegiatan seni dan sastra sangat efektif dalam mempertajam sikap-sikap tersebut. Siswa dapat diajak untuk mengapresiasi musik klasik, membuat atau mendengarkan musikalisasi puisi. Puisi selain dibacakan dapat pula dinyanyikan; atau kegiatankegiatan lain yang diminati siswa. Dalam hal ini, siswa dapat menulis puisi (pantun, syair, teka-teki, dan sejenisnya) dan mengaransemennya sehingga puisi itu dapat didendangkan. Kegitan ini memberikan beberapa keuntungan bagi siswa, di antaranya melatih siswa untuk lebih akrab dengan karya-karya klasik, menumbuhkan minat, mengasah rasa, dan membuat siswa bergembira.

\section{Pengembangan Materi}

Sebagaimana yang telah dipaparan sebelumnya bahwa sastra 
klasik cukup luas cakupannya. Namun, secara garis besar, sastra klasik terbagi ke dalam dua bagian, yakni berbentuk puisi (ada yang berupa mantra, pantun, gurindam, syair, dan sejenisnya), dan prosa (berbentuk hikayat, mite, fabel, parabel, dan legenda).

Di samping itu, penggolongan sastra klasik bisa dilakukan berdasarkan isinya. Karya-karya itu ada yang berupa (a) karya ilmu tauhid dan ilmu hukum Islam, (b) legenda yang bernapaskan keislaman, (c) mitos, (d) karya-karya bersejarah dan kisah perjalanan, (e) karya filsafat dan budi pekerti, dan (f) kitab undang-undang.

Ada pula penggolongan yang mencakup (a) cerita-cerita Alquran, (b) cerita Nabi Muhammad, (c) cerita sahabat Nabi Muhammad,(d) cerita pahlawan Islam, (e) sastra kitab.Penggolongan lain membagi sastra klasik itu ke dalam enam jenis, yakni (a) kisah tentang para nabi, (b) hikayat tentang Nabi Muhammad beserta keluarganya, (c) hikayat pahlawan-pahlawan Islam, (d) cerita tentang ajaran dan kepercayaan Islam, (e) cerita fiktif, dan (f) cerita mistik atau tasauf (Fang, 1993). Materi yang dikembangkan tetap mengacu pada kompetensi dasar (KD) di dalam kurikulum. Materi-materi yang berkenaan dengan sastra klasik di dalam KTSP Bahasa Indonesia SMP mencakup dongeng, syair, dan pantun. Adapun dalam KTSP Bahasa Indonesia SMA, sastra klasik itu mencakup pula gurindam dan hikayat. Keragaman teks itu tentu saja memerlukan pemahaman dan interpretasi yang mungkin berbeda-beda (Luxemburg, dkk, 1991: 25)

\section{Penggunaan Metode yangKreatif dan Inovatif}

Sastra kasik tidak sekadar untuk didengarkan ataupun dibaca. Tujuannya pun tidak sekadar siswa dapat mengetahui unsur-unsur intrinsik ataupun ekstrinsiknya. Akan tetapi lebih dari itu, terdapat berbagai cara agar nilai-nilai yang terdapat dalam karya tersebut bisa terinternalisasi dengan baik pada diri siswa. Untuk itu, teknik-teknik pembelajaran yang dapat digunakan antara lain sebagai berikut.

1) Mengkreasikan tokoh

Misalnya, siswa mengkreasikan cerita fabel tentang permusuhan kucing dengan anjing yang kemudian diubah versinya menjadi dua tokoh yang bersahabat kental. Dalam hal ini, siswa dapat memperoleh ilham dari film kartun Tom \& Jerry, yakni film yang sama-sama menceritakan dua binatang, tetapi antara kucing dengan tikus, yang kadang-kadang bermusuhan, kadang-kadang juga bersahabat.

2) Acak karakter

Untuk menghidupkan tokoh tertentu, siswa dapat melakukannya dengan saling mengisi karakter dari tokoh tertentu dari dongeng, hikayat, ataupun tokoh-tokoh dalam cerita lainnya. Misalnya, bila si Malikundang itu tidak durhaka pada ibunya atau si Kancil tiba-tiba menjadi kaya. Kemudian, para siswa pun melengkapinya konsekuensi dari karakter yang ditentukan itu. Hang Tuah tidak gagah lagi, misalnya, menjadi pemalu atau pendiam. Tokoh Pak Belalang biasanya selalu mujur diubah menjadi tokoh yang selalu mengalami kemalangan.

3) Melanjutkancerita

Guru menyediakan sebuahcerita dari suatu karya sastra klasik yang perlu dilanjutkan menjadi sebuah cerita yang lengkap. Para siswa melengkapi cerita itu dengan berbagai versi. Kelanjutan cerita dinilai berdasarkan daya tarik, kelogisan, dan keruntunannya. Teknik ini dapat menghadirkan kepribadian investigatif pada diri siswa (Zohar \& Marshal, 2001: 125126) 
4) Menulis profil tokoh cerita

Siswa diarahkan untuk melakukan kegiatan menulis dengan diawali mencari data mengenai tokoh tertentu di dalam cerita klasik. Dari sekiaan tokoh yang ada di dalam Hikayat Hang Tuah, misalnya, siswa hanya menentukan satu tokoh tertentu dan menuliskannya dengan karakter dan alur cerita tersendiri. Siswa dapat mengembangkan karakter tokoh itu berdasarkan versinya sendiri.

5) Menganalisis cerita

Teknik ini berguna ketika guru akan mengajarkan KD tentang memahami dongeng, hikayat, dan cerita-cerita sejenis. Setelah mendengarkan/ membaca dongeng, para siswa menganalisis daya tarik, karakter tokoh, dan unsur-unsur cerita itu, baik secara sendiri-sendiri ataupun berkelompok. Dalam teknik ini, setiap siswa mengemukakan pendapatnya dan ditanggapi oleh siswa yang lain yang dalam hal ini mereka dapat memanfaatkan gagasangagasan kunci (Djuharie, 2008: 9).

6) Mengkonstruksi pengalaman

Penerapannya dapat dilakukan sebagai berikut.

a) Siswa mengkonstruksi pengalaman dalam bentuk cerita lisan. Pengalaman itu, misalnya tentang kesan-kesan mereka setelah membaca/ menyimak dongeng, menonton sinetron yang ada kaitannya dengan sastra klasik, seperti si Malinkundang atau si Kabayan.

b) Siswa yang lain memberikan tanggapan-tanggapan atas daya tarik dan karakter tokoh yang dikagumi/ dibencinya.

c) Siswa didorong untuk merumuskan pengertian watak tokoh itu, misalnya tentang kesabaran dan kasih sayang beserta manfaatnya.

7) Bertanya dan menjawab

Masalah yang ditanyakan atau dijawab bisa berupa isi cerita, alur, karakter tokoh, dan unsur-unsur lainnya.

8) Menceritakan kembali

Teknik ini bisa diterapkan untuk KD menyampaikan cerita dan sejenisnya. Praktiknya, misalnya : (a) siswa memperhatikan suatu cerita dan mencatat pokok-pokoknya; (b) beberapa orang siswa menyampaikan kembali cerita itu secara bergiliran di depan kelas. Dalam kaitannya dengan pengembangan karakter, penceritaan itu dapat difokuskan pada karakter tokoh tertentu dari cerita itu.

9) Menyampaikan tanggapan

Masalah yang ditanggapi siswa bisa berupa karakter tokoh, alur, tema, amanat, dan hal-hal lain yang ada di dalam kurikulum. Tujuan yang diharapkan dari penerapan teknik ini adalah kecakapan siswa di dalam mengembangkan daya kritis, kelogisan penyampaian pendapat, dan kesantunan di dalam berbicara.

10) Bercerita

Teknik ini dapat digunakan untuk KD apapun. Fungsinya sebagai ilustrasi ataupun pengantar sebelum memasuki materi utama. Misalnya, untuk KD berbalas pantun. Guru bisa meminta ssiwa untuk menceritakan pengalamannya berkenaan dengan berbalas pantun. Di samping sebagai pengantar, teknik bercerita berguna untuk menciptakan suasana belajar yang lebih akrab dan menyenangkan. Guru pun dapat menggali potensi dan pemahaman siswa berkenaan dengan materi yang akan disampaikannya.

11) Menulis kata-kata bijak

Menulis kata-kata bijak biasanya dilakukan oleh para filosof setelah melewati tahap kontemplasi. Katakata bisa sering kali menjadi sugesti 
atau pemicu seseorang untuk menjadikannya sebagai orientasi atau pedoman hidup. Kata-kata bijak diharapkan dapat pula dibuat oleh siswa setelah membaca karya satra kasik tertentu.

\section{Pemanfaatan Media yang Tepat}

Pembelajaransastra

(klasik)

memerlukan media yang memiliki karakteristik sebagai berikut.

a. Memenuhi standar kecakapan berkomunikasi

KTSP untuk Mata Pelajaran Bahasa dan Sastra Indonesia mengembangkan semua aspek keterampilan berbahasa, termasuk di dalamnya adalah keterampilan mengapresiasi sastra (menyimak dan membaca). Pengembangan keterampilan tersebut merlukan media dengar. Tanpa penggunaan media tersebut, pengembangan keterampilan apresasi sastra tidak dapat berlangsung secara optimal. Demikian pula dengan pengembangan keterampilanketerampilan bersastra lainnya yang lebih menekankan pada performansi, seperti berbalas pantun, dramatisasi hikayat. Keterbatasan guru untukmenghadirkan model secaralangsung, dapat teratasi dengan pemanfaatan media yang dapat menjadi rujukan nyata bagi para siswa. Usaha tersebut akan terlaksana secara baik apabila ada media yang tepat yang mewakilinya.

b. Menggerakkan daya intelektual, batiniah, dan emosi siswa.

Media pembelajaran sastra haruslah membantu siswa dalam menghidupkan batiniah, kepekaan rasa, dan daya imajinasi. Media itu harus dapat pula membangkitkan emosi siswa sehingga pembelajaran mereka lebih berarti dan permanan (DePorter, 2010: 52). Dalam mengembangkan kemampuan mengapresiasi pantun, syair, gurindam, hikayat, dongeng, karyakaryaklasik lainnya, siswa memerlukan sejumlah kekayaan batiniah, daya imajinasi dan kepekaan rasa.Media-media belajar yang dihadirkan guru haruslah bias membantu mereka dalam memenuhi keperluan-keperluan itu.

c. Memperkaya kosakata

Berapresiasi dan berkreasi sastra yang baik berkaitan dengan sejumlah kata dan peristilahan yang harus dikuasai siswa. Di kelas-kelas rendah, hal itu sering menjadi kendala. Siswa tidak optimal di dalam kegiatan memaknai pantun, syair, dan karya-karya klasik lainnya banyak disebabkan oleh keterbatasan mereka akan kosakata tertentu. Kehadiran media tertentu diharapkan dapat membantu memperkaya kosakata mereka, terutama sebagai alat bantu di dalam pemahaman makna dan pelafalannya.

\section{Penyusunan Perangkat Evaluasi}

Secara umum evaluasi pembelajaran sastra dapat dikategorikan ke dalam tiga aspek, yakni pengetahuan sastra, apresiasi sastra, dan kreasi sastra.

a. Evaluasi pengetahuan sastra ditujukan untuk mengukur pemahaman siswa atas teori-teori kesastraan, seperti pengertian puisi klasik, ciri-ciri sastra klasik, dan jenis-jenisnya. Jenistagihan yang diberikan dapat berupa kuis, pertanyaan lisan/tertulis, tugas individu/kelompok.

b. Evaluasi apresiasi sastra ditujukan untuk mengukur penghayatan dan pandangan siswa terhadap karya-karya sastra klasik yang didengar/dintonton atau dibacanya. Karya-karya yang diapresiasi mencakup dongeng, hikayat, pantun, syair, dan karya-karya klasik lainnya. Adapun unsurunsurnya bias berkenaan dengan tema, amanat, tokoh dan penokohan, alur, 
latar, dan atau pusat pengisahan (Safari, 1997: 235-136)

c. Kreasi sastra ditujukan untuk mengukur keterampilan siswa di dalam menulis atau menampilkan/menggelar suatu karya sastra klasik.

1) Menulis karya sastra klasik, misalnya, berupa pantun, dongeng, hikayat.

2) Menampilkan/menggelar karya sastra berupa kegiatan pembacaan puisi lama, bercerita, dan bermain peran. Aspek yang dinilai dalam kegiatan tersebut bergantung pada jenis karya sastra ditampilannya.

\section{SIMPULAN}

Sastra klasik mengandung nilainilai kuhur yang sangat penting bagi perikehidupan bangsa. Nilai-nilai tersebut dapat dijadikan sumber ide yang sangat berharga. Wujud nilai yang diaktualisasikan di dalamnya merupakan sesuatu yang menarik bila dibandingkan dengan kenyataan moral yang berlaku pada masa kini. Semua bentuk moral di dalamnya membentuk gambaran tentang masyarakat dan kebudayaan Melayu pada masa lampau. Kita menjadi tahu tentang keteguhan mental mereka, ketaqwaan, pengendalian emosi, hubungan sosial, dan sikap-sikap lainnya dalam menghadapi aneka kenyataan hidup.

$$
\text { Sastra klasik menyimpan }
$$

karakteristik asli masyarakat dulu tentang berbagai kehidupannya. Sayangnya, saat ini karya-karya tersebut hampir-hampir terlupakan. Alasannya bahwa karya-karya tersebut sudah ketinggalan zaman, menggurui, membosankan, dan bahasa yang tidak dipahami. Anggapan tersebut tidak sepenuhnya benar. Sastra klasik penuh adegan konflik yang cukup membius, menantang para pembacanya untuk turut memcahkan berbagai persoalan kemasyarakatan, mendorong pembacanya untuk menyelami, perempati terhadap nasib dan posisi orang lain.
Dengan demikian, sastra klasik sangalah efektif di dalam membentuk karakter mulia, wahana penyambung budi pekerti asali bangsa kepada generasi bangsa. Untuk itu sekurang-kurangnya ada dua potensi yang dapat dikembangkan di dalam dari pengajaran sastra klasik sehubungan dengan pendidikan karakter. Pertama, pengajaran sastra itu harus mampu membina perasaan yang lebih tajam. Dibanding pelajaran-pelajaran lainnya, sastra klasik mempunyai kemungkinan lebih banyak untuk mengantarkan siswa di dalam mengenal jati diri kebangsaannya serta rangkaian kemungkinan hidup manusia seperti kebahagiaan, kebebasan, kesetiaan, kebanggaan diri sampai pada kelemahan, kekalahan, keputusasaan, kebencian, dan kematian. Seseorang yang banyak mendalami berbagai karya sastra biasanya mempunyai perasaan yang lebih peka untuk menunjuk hal mana yang bernilai dan mana yang tak bernilai. Secara umum, lebih lanjut sastra klasik akan mampu menghadapi masalahmasalah hidupnya dengan pemahaman, wawasan, toleransi dan rasa simpati yang lebih mendalam. Perlu digarisbawahi bahwa kedalaman itu merupakan satu kualitas yang dibutuhkan masyarakat di mana pun tanpa kecuali.

Potensi kedua sehubungan dengan pendidikan karakter adalah bahwa pengajaran sastra klasik dapat memberikan bantuan dalam usaha mengembangkan berbagai kualitas kepribadian siswa yang, antara lain, meliputi emosional, intelektual, sosial, dan moralitas. Sastra klasik dalam hal ini sangat potensial di dalam mengembangkan berbagai kecerdasan siswa dan memuat berbagai medan pengalaman yang sangat luas. Dalam beberapa pelajaran lain, siswa diharapkan mempelajari metode dan cara-cara yang dapat digunakan secara langsung untuk memecahkan berbagai masalah yang telah tersedia untuk latihan. Akan tetapi, 
dalam pengajaran sastra klasik dengan berbagai ciri khasnya, siswa dipertemukan dengan berbagai kesempatan untuk menelusuri semacam arus pengalaman berharga pada masa lalu yang bisa terus terus dialirkannya pada kehidupannya pada zaman sekarang. Pengalaman itu dapat membentuk kepribadian siswa yang lebih berkebangsaan, sebagai persiapan yang baik bagi kehidupan siswa dalam mengarungi arus global pada masa kini dan masa mendatang.Hanya saja untuk itu diperlukan strategi yang tepat di dalam pembelajarannya.

\section{UCAPAN TERIMA KASIH}

Penulis mengucapkan terima kasih kepada semua pihak yang telah banyak membantu mencerahkan dalam penulisan artikel ini, terutama kepada Prof. Dr. Didi Sukyadi, Dekan FPBS UniversitasPendidikan Indonesia, juga kepada rekan-rekan dosen pengampu mata kuliah sastra di Jurusan Pendidikan Bahasa dan Sastra Indonesia, yang telah berbagi ilmu dan wawasan tentang problematika kesastraan dan kepenulisannya.

\section{PUSTAKA RUJUKAN}

Al-Banjari, R,R. 2008. Membaca Kepribadian Manusia Seperti Membaca Alquran. Yogyakarta: Diva Press.

Chatib, M. 2010. Sekolahnya Manusia, Sekolah Berbasis Multiple Intelegences di Indonesi. Badung: Kaifa.

De Porter, B. 2010. Quantum Teaching, Mempraktikkan Quantum Learning di Ruang-ruang Kelas. Bandung: Kaifa.

Djahiri, A. K. 1996. Menelusuri Dunia Afektif, Nilai Moral, dan Pendidikan Nilai Moral. Laboratorium Pengajaran PMP Bandung.
Djuharie, O.S. 2008. Extensive Reading Top-Down Reading. Bandung: YramaWidya.

Esten, M.1999. Desentralisasi Kebudayaan. Bandung: Angkasa.

Fang, L,Y. 1993. Sejarah Kesusastraan Melayu Klasik. Jakarta: Erlangga.

Given, B, K. 2007. Brain-Based Teaching, Merancang Kegiatan Belajar-Mengajar yang Melibatkan Otak Emosional, Sosial, Kognitif, Kinestetis, dan Reflektif. Bandung: Kaifa.

Jensen, E. 2008. Brain-Based Learning, Pembelajaran Berbasis Kemampuan Otak, Cara Baru dalam Pengajaran dan Pelatihan. Yogyakarta: PustakaPelajar.

Kosasih, E. 2008. Khazanah Sastra Melayu Klasik. Jakarta: Nobel.

Luxemburg, J,V, dkk. 1991. Tentang Sastra. Jakarta: Intermasa.

Mustika, I. 2011. "Pembinaan Karakter Melalui Pembelajaran Sastra Berbasis Strategi Metakognitif" dalam Pendidikan Sastra \& Karakter Bangsa, FPBS UPI.

Permendiknas No. 22 tahun 2006 tentang Standar Isi untuk Satuan Pendidikan Dasar dan Menengah.

Rahmanto, B. 1988. Metode Pengajaran Sastra, Pegangan Guru Pengajar Sastra. Yogyakarta: Kanisius.

Ricoer, P.2002. Filsafat Wacana, Membelah Makna dalam Anatomi Bahasa. Yogyakarta: IRCiSoD.

Safari.1997. Pengujiandan Penilaian Bahasa dan Sastra Indonesia. Jakarta: Kartanegara.

Sumaryono, E.1993. Hermenetik, Sebuah Metode Filsafat. Yogyakarta: Kanisius.

Wellek, R dan Warren, A. 1989. Teori Kesusastraan (terjemahan Melani Budiarta). Jakarta: Gramedia.

Zohar, D, dan Marshal, I. 2001. SQ, Memanfaatkan Kecerdasan Spiritual dan Berpikir Integralistik dan Holistik untuk 
Memaknai Kehidupan. Bandung:

Mizan. 